\title{
Program specific admission testing and dropout for sports science students: a prospective cohort study
}

Lotte Dyhrberg O'Neill, kiropraktor, MMedEd, phd. Adjunkt ved Center for Medicinsk Uddannelse, Aarhus Universitet.

Mette Krogh Christensen, cand.scient, ph.d. Lektor ved Center for Medicinsk Uddannelse, Aarhus Universitet.

Maria Cecilie Vonsild, cand. scient. AC-fuldmægtig, Uddannelse og Kvalitet, Syddansk Universitet.

Birgitta Wallstedt, cand. scient. Kontorchef, Leder af SDU Universitetspædagogik, Syddansk Universitet.

\section{Reviewet artikel}

Recent research in medical education suggests that program specific admission testing could have a protective effect against early dropout. Little is known about the effect of program specific admission testing on dropout in other areas of higher education. The aim of this paper was to examine if admission strategy was also independently associated with dropout for sports science students in a university setting. The study design was a prospective cohort study with a 2 year follow-up. The population was 449 sports science students admitted to a university in the years 2002-2007. The analysis used was multivariate logistic regression and the predictors examined were: admission group (grade-based or admission tested) as well as educational and socio-demographic variables. The outcome was dropout within 2 years of study start. Admission testing offered superior protection against dropout compared to grade-based admission. This result may fit with elements of previous dropout theory, student-environment fit theory and perhaps also with self-efficacy theory.

\section{Introduction}

A universal model of student dropout from higher education does not exist and seems rather illusive, even though the literature on the topic appears to be abundant (Aldosary and Bala Garba 1999; SAU 2000). Student dropout is clearly multifactorial in nature (Georg 2009), but few models can in the end be all-encompassing (Tinto 1975). Tinto's (1975) sociologically orientated model of dropout in higher education appears to have been the single most influential dropout model for more than 40 years (Andres and Carpenter 1997; SAU 2000; Smith and Naylor 2001; Barefoot 2004; 
Georg 2009). Interestingly though, Tinto has in later years come to realize that the knowledge gained from the previous four decades of dropout theory research and development has failed to translate into institutional actions which work, and that there is a pressing need for 'more research on effective practice' which promotes student retention, such as classroom, curricular, grading and assessment practices and staff development programs (Tinto 2005; 2006). In this paper we argue that admission procedures be added to this list of effective practices to be investigated. In Tinto's (1975) original dropout model both students' initial commitments and their educational experiences were thought to have the potential to decisively influence dropout decisions (Figure 1). The research reported in this paper relates most directly to the first part of this conceptual model: the initial commitments of students to a program and/or institution.

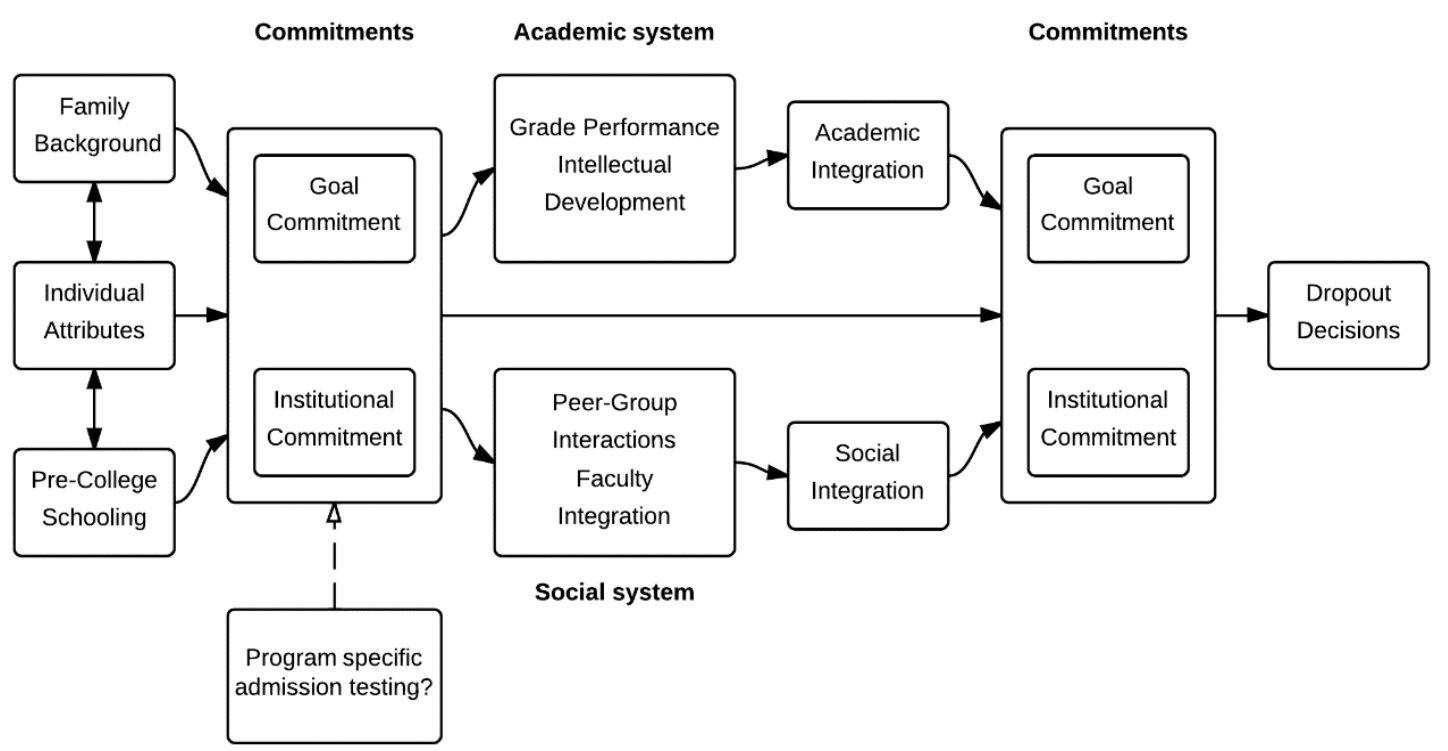

Figure 1: How 'program specific admission testing' may fit into Tinto's (1975) dropout model.

The importance of fit

Precisely because the initial commitment may be influential on dropout too, several authors have pointed to the importance of 'fit', i.e. a sufficient match between applicants and programs or institutions (Tinto 1983; Tinto 1990; Barefoot 2004; Benbassat and Baumal 2007; Georg 2009). Tinto (1983) stressed that people enter institutions of higher education with a great variety of commitments to the goals of higher education and also to the specific institution attended, and that since it is typically the case that dropout is highest in the first year of college, successful retention programs are 'integrally tied into the admission processes'. He suggested there would be much to gain from having institutions present or market themselves and their programs in more realistic and accurate ways, and that it appeared to be desirable to invite incoming students to visit the institutions and to meet the faculty and their future peers in advance (Tinto 1983). Evidence indicative of a connection 
between poor student-program fit and dropout has previously been reported in the literature (Nielsen 1991; Studiekontoret 1998; SAU 2000; Georg 2009).

\section{The best match}

Suspected less than optimal student-institutional fit also led the Faculty of Health Sciences at the University of Southern Denmark (USD) to experiment with new admission procedures for the different health science programs in 2002. The previous experience had been that too many health science students completed with considerable delays or dropped out, even though they were mainly selected via grade-based admission. The logical assumption was therefore, that pre-requisites other than just academic abilities might also be important for success at university. It was felt, that one significant pre-requisite for successful program completion, was that students choose the right program and/or institution from the outset. Hence, program specific admission criteria and selection procedures were designed to help 'the best match' between students and programs/institution. The 'best match' was assumed to come about partly via improved student selection, and partly by improved student self-selection. The purpose of the program specific admission criteria was therefore firstly, to make students aware of some relevant core competencies of the specific program, secondly to give students a chance to test and challenge themselves on these program specific competencies before starting their studies, and thirdly to select the students who best matched the program specific competencies from the outset. It was felt to be important that students were active, informed and involved in their choice of program and future profession. Finally, it was also thought to be very important that students had experienced the institution first hand, felt well qualified, as well as personally approved of and welcomed by the students and staff of the program. If 'initial student commitments' are important for subsequent decisions about dropping out as outlined by Tinto (1975) one would expect USD students who were selected via experimental admission track ('the best match' track) to be less likely to drop out during the early years of their studies than students who were admitted on academic merits alone (grade-based admission track).

The aim of this paper was therefore to examine if admission strategy was independently associated with dropout for sports science students at the Faculty of Health Sciences at USD. The objectives were to 1) examine if admission testing ('the best match' admission track) protected against dropout from the sports science program, and 2) to present a multivariate model of dropout for the cohorts examined. 


\section{Materials and methods}

Design

This was an observational study of an educational experiment with theoretical roots in epidemiology. The design is that of a prospective cohort study with 2 years of follow-up.

\section{Participants}

The population of interest was all the applicants admitted to the sports science program at USD in the years 2002-2007. Data on participants were collected from the student administrative database, a separate admission database for health science students, and a paper archive by a statistician and an assistant from the USD admission office in the spring of 2010. Hence, there was an 8 year time span of data collection (2002-2010) for the 6 cohorts (2002-2007 cohorts). The statistician was responsible for quality assurance of the extracted data. The USD data containing students' civil registration numbers was saved to a CD by the statistician, and sent to Statistics Denmark by registered mail in early May 2010 by the researchers. Statistics Denmark subsequently extracted the relevant data from their databases using students' civil registration numbers. The regional/local ethics review committee exempted this project from full review.

\section{Variables}

Variables from the university's databases. The variables obtained from USD databases were: admission strategy, exam type, gender, age, cohort, priority, transferal, pre-university grade point average (pu-GPA), and dropout status.

Admission strategies. Each year approximately $20 \%$ of available places were reserved for traditional grade-based admission. In the grade-based admission track students were admitted purely on having the highest pre-university GPA from an upper secondary exam. Grade-based students were selected first. The other approximately $80 \%$ of available places were designated the admission tested ('best match') students. The 'best match' students comprised of students with minimum pre-university GPA grades who were selected on the basis of a composite admission test score derived from a non-grade-based admission test battery. The admission test battery for sports science consisted of 8 individual elements: motivation, qualification, general knowledge, admission interview, swimming, ball games, gymnastics and dance/performance activities.

Motivation. To help select participants for the admission test a written motivational statement was required to be submitted to USD by applicants to the best match track. The motivational statement was an off-site written essay, the purpose of which was to assess written communication skills, knowledge of the 
chosen program and profession, reflections on past experiences, reflections on choice of study and future employment plans. Written motivation essays were rated by one staff member and given a score between $0-100$ on a global rating scale.

Qualification. In addition, applicants submitted a standard national application form, which contained specific questions pertaining to prior experiences and qualifications. This form was developed by the national Coordinated Application Board and was used for admission to all higher education programs in Denmark during 2002-2007. Scores were assigned (0-100 points) by one sports science staff member for: Relevance and quantity of previous work experiences, past educational qualifications, foreign exchange experiences, level of coaching, instructor or leadership experiences, and past sports related merits. Those who scored well on a weighted combination of the scores obtained these two tools (motivation and qualification) were eventually invited to an admission test day during which they: 1) sat a general knowledge test, 2) were interviewed, and 3) participated in a practical sports test which consisted of: swimming, ball games, gymnastics and dance/performance activities.

General knowledge test. The general knowledge test consisted of 60 multiple choice questions in the one-best-answer format to be completed in 15 minutes. The aim of this test was to select applicants with broad societal and cultural interests and curiosity towards knowledge in general, i.e. the specific content of the test was not designed to be relevant for sports science in particular. The content was as a consequence very broad with many sub-domains, e.g.: biology, physics, arts, news, music, health, politics, sports, culture, gastronomy etc. The number of correct answers obtained in this test was converted to a 0-100 percentage score.

Admission interview. The admission interview was a 25 minute semistructured interview to assess: The breadth of previous experiences, motivation and priorities, perspectives on post-graduate professional plans, knowledge of the sports science curriculum delivered at USD and of health science in general, attitude to current topics in sports and health science, personal interests and resources, as well as general interview behavior. Interview panels consisted of one staff and one student interviewer, and each panel interviewed 6-8 applicants. A score between 0100 on a global rating scale was given.

Swimming. Swimming consisted of: 8-10 minutes of breast stroke, 8-10 lanes of crawl/backstroke, and 2-3 freestyle dives from the $1 \mathrm{~m}$ springboard. The aim was to evaluate stamina, skills and the potential for completing the course of water activities which was part of the curriculum. The swimming activities lasted 30-40 minutes in total. A score between $0-100$ on a global rating scale was given by 1 member of staff who normally taught swimming in the program. 
Ball games. In ball games applicants were asked to participate in several different types of ball games for 50-60 minutes. They were evaluated on their technical and tactical skills and their potential for completing the elements of the curriculum pertaining to ball game activities. A score between 0-100 on a global rating scale was given by one member of staff with experience in teaching ball games.

Gymnastics. In gymnastics applicants were asked to complete a rhythmic warm up program. Afterwards, basic gymnastic skills were tested, such as: doing a hand stand, forward and backward rolls, turning cartwheels etc. The aim was to evaluate current skill level but also the potential for progression in skills and for completing the course of gymnastics in the curriculum. The time spent on gymnastic skills was 25 minutes. A score between $0-100$ on a global rating scale was given by one member of staff with experience in teaching gymnastics in this program.

Dance/performance. In dance/performance activities applicants did 10-12 minutes of dance/movement under instruction as well as 10-12 minutes of free-style movement. The aim was to evaluate applicants' sense of rhythm, their current ability to imitate and coordinate movement to music, but also their potential for learning by observation and their potential for completing the dance/performance activities in the curriculum. A member of staff with experience in teaching dance/performance in this program awarded a score between $0-100$ on a global rating scale.

The final admission test score was a weighted composite of all 8 elements described above. The composite reliability coefficient for the weighted composite of all 8 elements was examined in 2007 and reported to be 0.84 (O'Neill 2011c).

Exam type. Pre-university exam types were categorized into two categories: 'Gymnasium' or 'non-gymnasium'. Non-gymnasium exam types were: Higher Preparatory Exam, Higher Commercial Examination, Higher Technical Examination, special dispensations and foreign exam certificates.

Gender. Each student is registered in the student administrative database with a unique 8 digit civil registration number. Females ' civil registration numbers end with an even number, while those numbers belonging to males end with an odd number.

Age. Age refers to students' age on the first day in the program (study start). 
Cohort. Cohort refers to the year students were admitted. There were 6 admission cohorts in (years 2002-2007).

Priority. The national coordinated application form to higher education in Denmark allowed applicants to apply for and prioritize up to 8 educational programs simultaneously. We categorized priority in either 'first priority' or 'not first priority'.

Transferral. Transferral refers to a student who had previously been admitted to another program at USD and subsequently applied to the sports science program.

Pre-university grade point average (pu-GPA). Pu-GPA was the average grades obtained in any type of upper secondary education exam prior to university admission as measured on the Danish 7 point grade scale.

Dropout. Students were registered with dates for start, and termination or completion of studies in the student administrative database. Dropout was defined as having terminated studies at USD within 2 years from study start for any reason (withdrawal, dismissal or transferral). Hence, non-dropouts were defined as students who were still active (delayed or on time) or had completed studies.

Father's \& mother's education. Parents' education was categorized as either: 'university' education (Bachelor, Masters, or PhD-degrees), 'minimal' (lower secondary education only), or 'other' educations.

\section{Analysis}

We consulted an experienced biostatistician in the design stage as well as in the conclusion stages of this study. Descriptions of all variables delivered by the USD Admission Office and Statistics Denmark were scrutinized to check for signs of changes in data collection methods. The variables set forth in the research protocol were either prepared for analysis (USD data) or generated from merging various datasets (Statistics Denmark variables). Missing data for the social variables generated from Statistics Denmark data (parents' education) were categorized separately and summary tables produced. All variables were subsequently examined for collinearity and zero cells before analyses, by inspection of matrix graph plots, $2 \mathrm{x}$ 2 tables and boxplots (Menard 2002). Individual predictors of dropout were then examined with univariate logistic regression analyses. After consulting a biostatistician, it was decided and documented in the analysis plan that variables with a $\mathrm{p}<0.1$ were to be included in a multivariate model. Multivariate logistic regression was used to analyze the dichotomous outcome of dropout/non-dropout. Post-estimation diagnostics of models consisted mainly of checking linearity 
assumptions and influential data-points. Additivity was assumed because we did not want to risk over-fitting models through inclusion of interactions due to the relatively large number of potential predictors and the modest number of dropouts.

\section{Results}

During the period 2002-2007 there were 185-245 applicants to the sports science program each year. Of these, 70-80 were admitted annually via one of the two admission tracks. However, every year a small group of applicants (ca. 5-30 per year) did not turn up for the admission tests despite having applied, being eligible and receiving an invitation to participate, so some degree of self-selection was definitely observed in connection with admission testing (the 'best match' admission track). In the years 2002-2007 a total of 449 applicants were eventually admitted to the sports science program of which 441 were Danish citizens (Table 1).

Two years after study start $17.6 \%$ (79/449) of the total population were registered as dropouts. The dropout rate amongst students in the grade-based admission track was $29.8 \%(14 / 47)$ as opposed to $16.2 \%$ (65/402) amongst the 'best match' admitted students, even though the mean pre-university grade point averages were considerably higher for the grade-based admission group $(9.30 \sim$ very good) compared to that of the 'best match' students $(6.50 \sim$ good $)$. This grade difference amongst the two admission groups was also statistically significant $(\mathrm{df}=442, \mathrm{t}=-14.059, \mathrm{p}<0.001)$. 


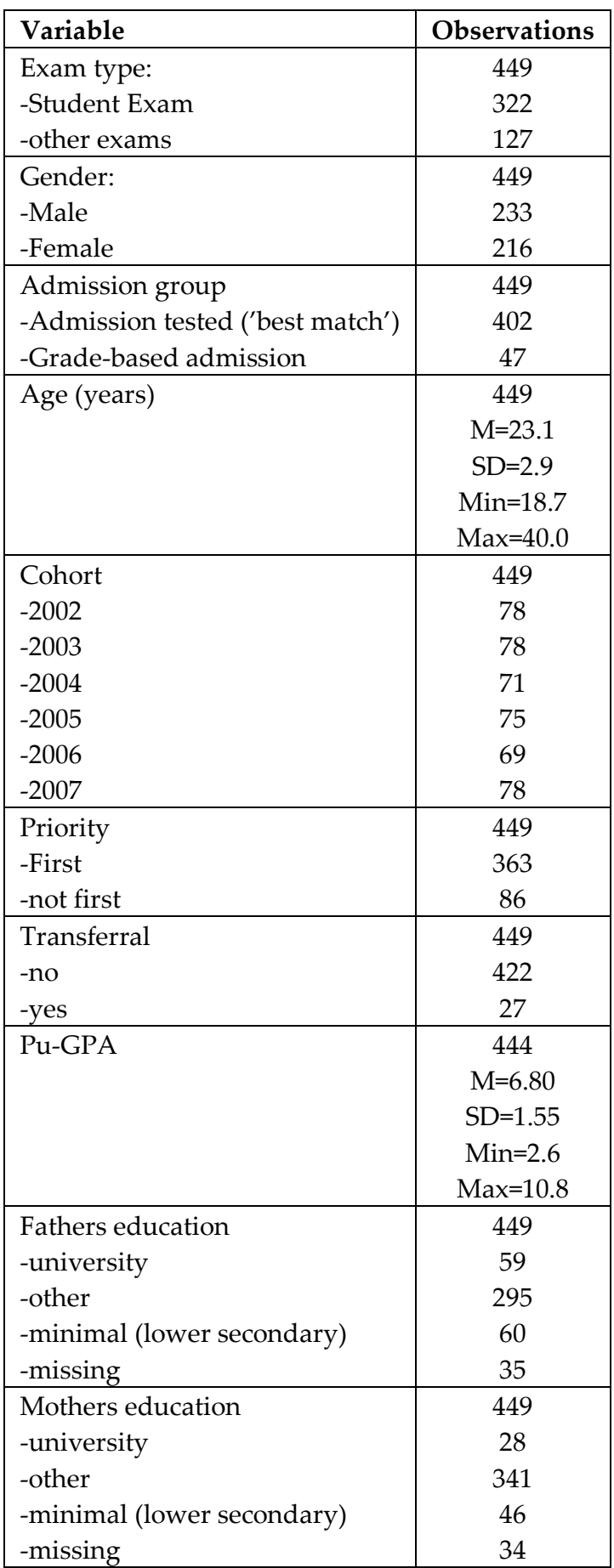

Table 1: All admitted sports science students from 2002-2007 (N=449) - Note: M=mean, SD=standard deviation, min=minimum, max = maximum . 
Notably, the pu-GPA was not a significant predictor of dropout two years from study start (univariate model, Table 2). In contrast, the type of qualifying exam, gender and admission group ('best match' or not) survived as statistically significant individual predictors of dropout in a multivariate model (Table 2). The odds of dropping out were 2.41 times higher for students without the gymnasium exam certificate compared to students with this type of upper secondary education (table 2). Female sports science students' odds of dropping out were 2.21 times higher than that of their male counterparts (Table 2). The odds of dropping out were 2.22 times larger for students in the grade-based admission group compared to students in the best-match admission group (Table 2).

\begin{tabular}{|c|c|c|c|c|}
\hline \multirow[t]{2}{*}{ Variables } & \multicolumn{2}{|c|}{$\begin{array}{c}\text { Univariate } \\
\text { analyses }\end{array}$} & \multicolumn{2}{|c|}{$\begin{array}{c}\text { Multivariate } \\
\text { model }\end{array}$} \\
\hline & OR $\left[\mathrm{CI}_{95 \%}\right]$ & $\mathrm{p}$ & OR $\left[\mathrm{CI}_{95 \%}\right.$ ] & $\mathrm{p}$ \\
\hline Grade-based admission & $2.20[1.12-4.34]$ & 0.023 & $2.22[1.05-4.71]$ & 0.038 \\
\hline Non-gymnasium exam & $2.57[1.55-4.24]$ & 0.000 & $2.41[1.38-4.21]$ & 0.002 \\
\hline Female & $1.86[1.13-3.06]$ & 0.014 & $2.21[1.30-3.74]$ & 0.003 \\
\hline Age & 1.09 [1.01-1.17] & 0.031 & 1.09 [0.99-1.20] & 0.067 \\
\hline Cohort: & & $0.198^{\mathrm{a}}$ & & \\
\hline-2003 & $2.39[1.07-5.36]$ & 0.034 & & \\
\hline-2004 & $1.24[0.51-3.02]$ & 0.637 & & \\
\hline-2005 & $1.05[0.42-2.58]$ & 0.921 & & \\
\hline-2006 & $1.16[0.47-2.86]$ & 0.755 & & \\
\hline-2007 & $1.11[0.46-2.69]$ & 0.821 & & \\
\hline Not the first priority program & $1.43[0.80-2.56]$ & 0.225 & & \\
\hline Transferral & $1.37[0.53-3.50]$ & 0.516 & & \\
\hline Pu-GPA & $1.01[0.86-1.18]$ & 0.950 & & \\
\hline Fathers education & & $0.882^{\mathrm{a}}$ & & \\
\hline -university & $1.28[0.63-2.59]$ & 0.490 & - & \\
\hline -minimal (lower secondary) & $1.13[0.55-2.32]$ & 0.746 & & \\
\hline -missing & $1.26[0.52-3.04]$ & 0.614 & & \\
\hline Mothers education & & $0.412^{\mathrm{a}}$ & & \\
\hline -university & $0.85[0.28-2.54]$ & 0.769 & & \\
\hline -minimal (lower secondary) & $1.41[0.66-3.01]$ & 0.370 & & \\
\hline -missing & $1.83[0.81-4.13]$ & 0.145 & & \\
\hline $\mathrm{N}_{\text {obs }}$ & - & & 449 & \\
\hline $\mathrm{R}^{2}$ & - & & 0.069 & \\
\hline
\end{tabular}

Table 1: Dropout model for sports science students admitted from 2002-2007 - Note: OR=odds ratio, CI95\%=95\% confidence interval, $p=p$-value. The OR's presented for the variable categories in table 2 are relative to the reference categories. Reference categories were: entering the program via test-based admission ('the best match' students), having a gymnasium exam, being of male gender, belonging to the 2002 cohort, assigning first priority to the program on the application form, not having transferred from another program at USD, fathers education='other', mothers education='other'. ' the $p$-value for the overall variable. 


\section{Discussion}

We examined the predictors of dropout 2 years from study start for 449 sports science students representing 6 years of student intake. We found that nongymnasium upper secondary exams, female gender and grade-based admission predicted dropout in a multivariate model. Participating in the 'best match' admission test track appeared to protect against early dropout. Self-selection to the best-match admission track was observed.

Grades. We found that pre-university grades were not predictors of subsequent dropout for these particular students in this particular setting, which is in contrast to global findings in higher education (Tinto 1975; Studiekontoret 1998; Kristensen 1998; SAU 2000; RAU 2002). Our apparently 'conflicting' result simply illustrates an important point: just because there may be a general tendency for lower pre-university grades to predict dropout across a majority of university programs which mainly use grade-based admission, one cannot assume in advance, that nongrade criteria are inferior to grade-based criteria when the outcome of interest is dropout/retention. An explanation for the result that prior grades did not predict dropout while program specific admission testing did, could be if year 1 and 2 of the sports science curriculum were less demanding academically, but perhaps more demanding of practical sports skills, which also constitute an important part of the admission test.

Qualifying exam type. The fact that the type of qualifying exam matters to dropout (table 2) has been found previously in Danish dropout research both at individual program level (Nielsen 1991; Kristensen 1998; O'Neill et al. 2011b) and for whole university cohorts (SAU 2000; RAU 2002).

Gender. Generally speaking, gender does not appear to be associated with dropout at university level in Denmark (SAU 2000; RAU 2002; Mølgaard et al. 2003), though it may be different in individual programs (Kristensen 1998). We found that females' odds of dropping out within 2 years from study start were 2.2 times higher than those of the men, in spite of the fact that men and women were almost equally represented amongst the admitted applicants, i.e. from study start (table 1). One possible explanation for the females' increased risk of dropping out may be the powerful influence of gender construction and gender negotiation in sports and physical education (PE). Girls' struggles in PE are a well-described subject in the literature on education and careers in sport and PE (Flintoff and Scraton 2006; Brown and Evans 2002; Dowling 2006).

Test-based admission. Unfortunately, we have not been able to find any studies of selection procedures and dropout in sports science programs at university for direct comparison with our results. We suspect that not many university 
programs experiment with parallel admission tracks which allow them to compare directly the effect of different admission procedures on for instance dropout or other educational performance outcomes. One field in higher education in which a few recent studies for comparison have emerged is the field of medical education. Prior to 2009 , it seems there were no good quality comparative studies of admission procedure's effect on drop out in medical education ( $\mathrm{O}^{\prime}$ Neill 2011a), but since then three studies have been published. All three find that selection by admission testing (irrespective of type and setting) seems to protect against dropout to some extent (Table 3). Our results for the sports science students would indicate a similar effect of admission testing (Table 2). Of course, we cannot rule out that publication bias may have prevented similar studies of sports science/PE admission testing which showed negative results of testing on retention from being published in the past.

\begin{tabular}{|c|c|c|c|}
\hline $\begin{array}{l}\text { First } \\
\text { author } \\
\text { year }\end{array}$ & Description & Outcome & Effect \\
\hline $\begin{array}{l}\text { O'Neill }^{\prime} \\
2011 b\end{array}$ & $\begin{array}{l}\text { Participants: All } 1544 \text { medical students } \\
\text { at University of Southern Denmark } \\
\text { admitted in 2002-2007. Predictors: } \\
\text { admission group (grade-based versus } \\
\text { test-based admission), age, cohort, } \\
\text { gender, prior exam type, program } \\
\text { priority on application, prior transfers, } \\
\text { doctor parent, ethnic origin, } \\
\text { parenthood, parents living together, } \\
\text { parent on benefit, university educated } \\
\text { father/mother. Follow up: } 2 \text { years. } \\
\text { Analysis: Multivariate logistic } \\
\text { regression. }\end{array}$ & $\begin{array}{l}\text { Dropout: } \\
\text { termination of } \\
\text { studies within } 2 \\
\text { years from study } \\
\text { start for any } \\
\text { reason } \\
\text { (withdrawal, } \\
\text { dismissal or } \\
\text { transferral). }\end{array}$ & $\begin{array}{l}\text { Admission testing: odds } \\
\text { ratio }=0.58, C_{95 \%}:[0.37- \\
0.90] \\
\text { Dropout rates: } \\
\text {-Grade-based admission } \\
\text { group }=11.6 \%(84 / 722) \\
\text {-Test-based admission } \\
\text { group }=7.4 \%(61 / 822)\end{array}$ \\
\hline $\begin{array}{l}\text { Reibnegger } \\
2011\end{array}$ & $\begin{array}{l}\text { Participants: All } 2860 \text { medical students } \\
\text { admitted at the Medical University of } \\
\text { Graz, Austria in 2002-2008. Predictors: } \\
\text { mode of admission (test-based } \\
\text { admission versus free admission), } \\
\text { gender, age, nationality. Follow-up: } \\
\text { 1.5-7.5 years. Analysis: Non-parametric } \\
\text { and semi-parametric survival analysis. }\end{array}$ & $\begin{array}{l}\text { Dropout: being } \\
\text { registered by the } \\
\text { university with a } \\
\text { dropout date } \\
\text { before February } \\
28,2010 \text {. }\end{array}$ & $\begin{array}{l}\text { Selection: hazard ratio= } \\
0.145, \text { CI95\%: }[0.106-0.198] . \\
\text { Dropout rates: } \\
\text {-Free admission group= } \\
38.8 \%(764 / 1971) \\
\text {-Test-based admission } \\
\text { group }=4.6 \%(41 / 889)\end{array}$ \\
\hline $\begin{array}{l}\text { Urlings- } \\
\text { Strop } 2009\end{array}$ & $\begin{array}{l}\text { Participants: } 1327 \text { admitted medical } \\
\text { students at Erasmus Medical School, } \\
\text { Holland in 2001-2004. Groups } \\
\text { compared: Test-based admission group } \\
\text { versus a lottery admission group. } \\
\text { Strata: year of entrance, weighted } \\
\text { lottery category, pre-university GPA. } \\
\text { Follow up: } 2-4 \text { years. Analysis: Mantel- } \\
\text { Haentzel stratification test. }\end{array}$ & $\begin{array}{l}\text { Dropouts: } \\
\text { students earning } \\
<60 \text { ECTS during } \\
\text { the first } 2 \text { years of } \\
\text { study. }\end{array}$ & $\begin{array}{l}\text { Lottery admission: } \\
\text { relative risk=2.58, } \\
\text { CI95\%[1.59-4.17] } \\
\text { Dropout rates: } \\
\text {-Lottery admission } \\
\text { group }=14.9 \%(140 / 938) \\
\text {-Test-based admission } \\
\text { group }=6.2 \%(24 / 389)\end{array}$ \\
\hline
\end{tabular}

Table 2: Admission testing and dropout in medical education. 
Possible mechanisms. The aim of our research was to examine if (not why and how) admission testing protected against dropout from the sports science program compared to grade-based admission. However, we still consider it in order to very briefly speculate on why and how admission testing could theoretically provide some degree of protection against dropout. A protective effect of admission testing may fit with elements of Tinto's (1975) dropout model (i.e. the importance of students' initial commitments), but also with Person-Environment Fit Theory. Research grounded in this theory has indicated that congruence between person and environments is critical to the success of college students, as measured by educational stability, satisfaction and achievement (Witt and Handel 1984; Feldman et al. 1999; Smart et al. 2000; Porter and Umbach 2006). According to this theory, institutional programs that promote student-institutional fit from the beginning will produce more satisfied students with a greater chance of achieving both academic and personal goals. In addition, Self-Efficacy Theory could also explain why admission testing would be associated with persistence (Bandura 1997). Self-efficacy refers to an individual's perceived capabilities for learning or performing actions at designated levels (Bandura 1997; Schunk and Pajares 2009). Self-efficacy has been shown to influence motivation, achievement and self-regulation, and in education it has been found to affect students' choices of activities, effort expended, persistence, interest and achievement (Schunk and Pajares 2009).

Limitations of this study. One limitation of this study is the potential bias introduced by missing data from Statistics Denmark. In addition, there is also always the potential for misclassification of variables, as data had to be retrieved and pieced together from different sources (databases, archive), coded and merged etc. We deliberately chose to look at dropout two years from study start as our outcome to ensure the largest possible sample sizes, because it is our experience that dropout is generally concentrated in the first 2 years of study, but of course it is a limitation that we did not follow everybody to either dropout or program completion.

\section{Conclusion}

Program specific admission testing appeared to protect against early dropout for the cohorts of sports science university students we studied. Program specific admission testing could be one way of improving student-institutional fit very early on in the program, in addition to retention strategies directed at improving curricula and the teaching and learning experience. The proposed protective effect of admission testing may well fit both with: elements of Tinto's (1975) dropout model (the importance of students' initial commitments), Person-Environment Fit Theory and Self-Efficacy Theory. More studies examining the protective effect of admission testing in university settings on dropout are needed. 


\title{
Acknowledgements
}

The authors would like to thank the following staff at the Admissions Office at the University of Southern Denmark: statistician Henrik Bahne for his help with the extraction and quality assurance of data, head of section for analysis and quality development, Jacob Jensen, for inspiration, and deputy director Annette Schmidt, for approving this project. In addition, the authors would like to thank biostatistician Lars Korsholm for statistical and methodological advice in this piece of research.

\section{Funding}

The funding for this project was shared by the European Social Fund, the Institute of Sports Science and Clinical Biomechanics, University of Southern Denmark, as well as the Unit for Education Development at the same institution.

Lotte Dyhrberg O'Neill er adjunkt ved Center for Medicinsk Uddannelse, Aarhus Universitet og tidligere pædagogisk medarbejder ved Enheden for Uddannelsesudvikling på Syddansk Universitet, hvor hun bl.a. har arbejdet med kvote 2 optagelsen på kiropraktorstudiet og medicinstudiet. Forfatter til en række artikler om optagelse og frafald i både danske og engelsksprogede tidsskrifter.

Mette Krogh Christensen er lektor ved Center for Medicinsk Uddannelse ved Aarhus Universitet, hvor hun forsker $i$ samspillet mellem uddannelsesmiljø og individuel faglig udvikling på de sundhedsvidenskabelige uddannelser, herunder især talentudvikling og karrierebaner inden for medicin og ph.d.-uddannelsen. Mette er forfatter til en række overvejende engelsksprogede artikler om sociale og psykologiske aspekter af talentudvikling.

\begin{abstract}
Maria Cecilie Vonsild er AC-fuldmægtig ved Uddannelse og Kvalitet på Det Sundhedsvidenskabelige Fakultetssekretariat på Syddansk Universitet, hoor hun bl.a. er projektleder for kvote 2 optagelsesprøverne på idrætsstudiet, kiropraktorstudiet, psykologistudiet og medicinstudiet.

Birgitta Wallstedt var pædagogisk chefkonsulent for Enheden for Uddannelsesudvikling på Sundhedsvidenskabelige Fakultetssekretariat ved Syddansk Universitet og primus motor for implementering af kvote 2 optagelsesprøverne på sundhedsvidenskab. Hun har publiceret på dansk og engelsk om optagelse og frafald.
\end{abstract}

\section{References}

Aldosary, A. S., \& Bala Garba, S. (1999). An analysis of factors contributing to college student dropout in a medium sized technical university: the case of the King Fahd University of Petroleum and Minerals Dhahran, Saudi Arabia. Higher Education Policy, 12, 313-328.

Andres L., \& Carpenter S. (1997). Today's Higher Education Students: Issues of Admission, Retention, Transfer, and Attrition in Relation to Changing Student Demographics. Vancouver: University of British Columbia.

Bandura A. (1997). Self-efficacy: the exercise of control. New York: Freeman.

Barefoot B. O. (2004). Higher education's revolving door: confronting the problem of student drop out in US colleges and universities. Journal of Open Distance Elearning, 19, 9-18. 
Benbassat J., \& Baumal R. (2007). Uncertainties in the selection of applicants for medical school. Advances in Health Science Education, 12, 509-529.

Brown D., \& Evans J. (2004). Reproducing gender? Intergenerational links and the male PE teacher as a cultural conduit in teaching physical education. Journal of Teaching in Physical Education, 23, 48-70.

Dowling F. (2006). Physical education teacher educators' professional identities, continuing professional development and the issue of gender equality. Physical Education and Sport Pedagogy, 11, 247-263.

Feldman K. A., Smart J. C., \& Ethington C. (1999). Major field and personenvironment fit: Using Holland's theory to study change and stability in college students. Journal of Higher Education, 70, 642-669.

Flintoff A., \& Scraton S. Girls and physical education. (2006). In D. Kirk, D. Macdonald, \& M. O'Sullivan (Eds.), The handbook of physical education (pp. 767783). London: Sage.

Georg W. (2009). Individual and institutional factors in the tendency to drop out of higher education: a multilevel analysis using data from the Konstanz Student Survey. Studies in Higher Education, 34, 647-661.

Kristensen I. P. Tidsforbrug på studiet - Studiestatistik rapport nr. 6. (1988). Århus: Institut for Statskundskab, Aarhus Universitet.

Menard S. (2002). Applied logistic regression analysis. 2nd ed. Thousand Oaks: Sage.

Mølgaard P.K., Lange J., Lefmann A. K., Melin L., \& Markvard M. (2003). Ophørsundersøgelse årgang 2000. En register- og spørgeskema undersøgelse. Copenhagen: University of Copenhagen.

O'Neill L. D. (2011c). Admission tests in medical education. Generalizability, predictive validity and dropout (thesis). Odense: Syddansk Universitet.

O'Neill L., Hartvigsen J., Wallstedt B., Korsholm L., \& Eika B. (2011b). Medical school dropout - testing at admission versus selection by highest grades as predictors. Medical Education, 45, 1111-1120.

O’Neill L., Korsholm L., Wallstedt B., Eika B., Hartvigsen J. (2009). Generalizability of a composite student selection programme. Medical Education, 43, 58-65.

O'Neill L. D., Wallstedt B., Eika B., \& Hartvigsen J. (2011a). Factors associated with dropout in medical education: a literature review. Medical Education, 45, 440454.

Nielsen Å. A. (1991). Frafald eller Studieophør? Aarhus: Psykologisk institut, Aarhus Universitet.

Registraturen, Aarhus Universitet (RAU). (2002). Den blå årgang - en forløbsundersøgelse af årgang 2000. Aarhus: Aarhus Universitet.

Reibnegger G., Caluba H. C., Ithaler D., Manhal S., Neges H. M., \& Smolle J. (2011). Dropout rates in medical students at one school before and after the installation of admission tests in Austria. Academic Medicine, 86, 1040-1048.

Schunk D. H., \& Pajares F. (2009). Self-efficacy theory. In K. R. Wentzel, \& A. 
Wigfield (Eds.), Handbook of motivation at school (pp. 35-55). New York: Routledge.

Smart J.C., Feldman K.A., \& Ethington C.A. (2000). Academic disciplines: Holland's theories and the study of college students and faculty. Nashville, TN: Vanderbilt University Press.

Smith J.P, \& Naylor R.A. (2001). Dropping out of university: a statistical analysis of the probability of withdrawal for UK university students. Journal of the Royal Statistical Society, 64, 389-405.

Studenterrådet ved Aarhus Universitet (SAU). (2000). Frafald og studiemiljø. Aarhus: Studenterrådet ved Aarhus Universitet.

Studiekontoret. (1998). Den Grønne Årgang - en forløbsundersøgelse af årgang 1995. Århus; Aarhus Universitet.

Urlings-Strop L. C., Stijnen T., Themmen A. P. N., Splinter T. A. W. (2009). Selection of medical students: a controlled experiment. Medical Education, 43, 175-183.

Porter S.R., Umbach P.D. (2006). Collge major choice: an analysis of personenvironment fit. Research in Higher Education, 47, 429-449.

Tinto V. (1975). Dropouts from higher education: A theoretical synthesis of recent research. Review of Educational Research, 45, 89-125.

Tinto V. (1983). Limits of theory and practice in student attrition. Journal of Higher Education, 53: 687-700.

Tinto V. (1990). Principles of effective retention. Journal of the Freshman Year Experience, 2, 35-48.

Tinto V. (2005). Epilogue: Moving from theory to action. In A. Seidman (Ed.), College student retention: Formula for student success (pp. 317-333). Westport, CT: ACE/Praeger.

Tinto V. (2006). Research and practice of student retention: what next? Journal of College Student Retention, 8, 1-19.

Witt P. H., \& Handal P. J. (1984). Person-environment fit - is satisfaction predicted by congruency, environment or personality? Journal of College Student Development, 25, 503-508. 